\title{
Xenoestrogens diethylstilbestrol and zearalenone negatively influence pubertal rat's testis
}

\author{
Eliza Filipiak1, Renata Walczak-Jedrzejowska², Elzbieta Oszukowska², \\ Anna Guminska1, Katarzyna Marchlewska1 ${ }^{1}$, Krzysztof Kula ${ }^{2}$, \\ Jolanta Slowikowska-Hilczer ${ }^{1}$
}

\author{
${ }^{1}$ Division of Reproductive Endocrinology, Medical University of Lodz, Poland \\ ${ }^{2}$ Division of Andrology, Medical University of Lodz, Poland
}

\begin{abstract}
The aim of this study was to assess the impact of xenoestrogens: diethylstilbestrol (DES) and zearalenone (ZEA) on rat's pubertal testis and to compare it with the effect of natural estrogen - $17 \beta$-estradiol (E). Male Wistar rats were daily, subcutaneously injected at $5^{\text {th }}-15^{\text {th }}$ postnatal days (p.d.) with E $(1.25$ or $12.5 \mu \mathrm{g})$ or DES (1.25 or $\left.12.5 \mu \mathrm{g}\right)$ or ZEA (4 or $\left.40 \mu \mathrm{g}\right)$ or vehicle. At $16^{\text {th }}$ p.d. testes were dissected, weighted, and paraffin embedded. Following parameters were assessed: diameter and length of seminiferous tubule, numbers of spermatogonia $A+$ intermediate $+B(A / I n / B)$, preleptotene spermatocytes (PL), leptotene+zygotene+pachytene spermatocytes (L/Z/PA) and Sertoli cells per testis. Testes weight, seminiferous tubule diameter and length were decreased by both doses of E, DES and ZEA. DES effect was the strongest, but its influence on testis weight and seminiferous tubule length, on the contrary to E and ZEA, was not dose-dependent. Similarly, DES in both doses had the most severe negative impact on the number of germ and Sertoli cells. The negative influence of E on germ cells was less pronounced. The negative effect of ZEA was seen only after administration of the higher dose on spermatogonia number, while DES and E decreased A/In/B number more evidently. Sertoli cell number were decreased after both doses of E. ZEA40 decreased Sertoli cell number while ZEA4 had no effect. Conclusion: exposure of prepubertal male rat to DES has the strongest detrimental effect on the developing testis in comparison to E and ZEA. Both, E and DES, decreased number of germ and Sertoli cells, diminished seminiferous tubule diameter, length and testis weight. ZEA had much more weaker effect than the potent estrogens.
\end{abstract}

Key words: rat, testis, spermatogenesis, estradiol, xenoestrogens, zearalenone, diethylstilbestrol

\section{Introduction}

Although estrogens seem to be mainly female sex hormones, they have important physiological roles in many organs and systems in the male e.g. bones, brain, nervous, cardiovascular and reproductive systems [1-3]. Estrogens exert their biological role by binding to estrogen receptor (ER). Both ER types, $\alpha$ and $\beta$, can be found widely in the male reproductive system. However, different research results are not in accordance when concerning the localization of ER $\alpha$ and $\mathrm{ER} \beta$, particularly in the testis [3]. It was shown in many studies that after birth, in the neonatal and peripubertal period of life, the expression of ER $\alpha$ is

Correspondence: J. Slowikowska-Hilczer, Division of

Reproductive Endocrinology, Dept. of Andrology and Reproductive Endocrinology Medical University of Lodz, Sterlinga Str. 5, 91-424 Lodz, Poland; tel./fax.: (+4842) 6330705, e-mail: slowikowska.hilczer@csk.umed.lodz.pl limited to the Leydig cells in rodents and stallions [4] but the expression of ER $\beta$ in rats is present in germ and somatic testicular cells, including Leydig or Sertoli cells $[5,6]$. In 4-day-old rats fetal germ cells (gonocytes) reveal ER $\beta$ mRNA in their cytoplasm and ER $\beta$ protein in their nucleus. Between the $10^{\text {th }}$ and $26^{\text {th }}$ day of life the presence of ER $\beta$ mRNA and protein were detected in both spermatogonia A and pachytene spermatocytes. It seems that the other germ cells do not show ER $\beta$ staining at this time [6].

Besides the physiological function of natural estrogens in the reproductive system, compounds with estrogenic activity, called xenoestrogens, are reported to be responsible for some disorders e.g. testicular cancer and infertility $[7,8]$. Xenoestrogens belong to endocrine disrupting compounds, a group of substances which can interact with and modulate the function of endocrine system. They can interfere with the hormone biosynthesis, increase or decrease the rate of hormone metabolism or elimination and alter hormone 
homeostasis [9]. Many of them are spread worldwide, deposited in environment, persistent to degradation, can accumulate in food webs and are harmful not only to the present but potentially also to the next generations. Xenoestrogens are structurally diverse group and can be found among medicines, pesticides, industrial chemicals and natural substances. Although, chemically different they can bind to ER and exert effects to some extent similar to natural estrogens.

One of the most known compounds with the high estrogenic activity and detrimental effect on the reproductive system is diethylstilbestrol (DES), a synthetic potent estrogen, which was widely used from 40 . to 70 . of the $20^{\text {th }}$ century for the treatment of pregnant women to prevent miscarriages. What appeared later on, DES caused serious abnormalities in male and female reproductive tracts and problems with fertility in carried offsprings [9]. Testicular tumors and cryptorchidism appeared in mice exposed to DES in utero [10]. Exposure to DES in early postnatal life showed decreased Sertoli cell number, germ cell volume and spermatogenesis efficiency in adult rats [11].

Dietary estrogens originate not only from plants but also from food contamination with moulds e.g. Fusarium $s p$., which produces a mycotoxin zearalenone (ZEA). It contaminates grains when they are grown and stored in too wet conditions. ZEA is known to bind to ER in vitro and in vivo [12] and was reported to decrease embryonic survival, litter size, to cause disorders of male and female reproductive system in laboratory and domestic animals, and to have toxic effects in human [13]. It was found that ZEA caused germ cell apoptosis in male rats [14] and diminished boar sperm quality (stability of chromatin structure, sperm viability and motility) in vitro [15].

A lot of studies were dedicated to the influence of xenoestrogens on the male reproductive system during fetal period of life $[9,16]$ and only few dealt with the postnatal development [17-19]. An objective of our study was to assess the influence of different doses of xenoestrogens: DES and ZEA on testicular development and quantitative aspects of spermatogenesis in pubertal rats and to compare results with the effect of natural estrogen $-17 \beta$-estradiol (E).

\section{Materials and methods}

Experimental setup. An experiment was performed on newborn male Wistar rats. Animals were maintained at stable temperature $\left(22^{\circ} \mathrm{C}\right)$ and 12 hours light/dark cycle. From the first day of pregnancy and then, after parturition, feeding mothers had free access to water and soy-free food (Agropol, Poland). Newborn rats, were subcutaneously injected daily, from the $5^{\text {th }}$ to $15^{\text {th }}$ postnatal day (p.d.), with: 1) $\mathrm{E}$ in doses -1.25 or $12.5 \mu \mathrm{g}$, or 2) DES -1.25 or $12.5 \mu \mathrm{g}$, or 3) ZEA -4 or $40 \mu \mathrm{g}$. A volume of each injection was $0.1 \mathrm{ml}$. The dose of $12.5 \mu \mathrm{g}$ of $\mathrm{E}$ was chosen on the analogy of the dose of estradiol benzoate, administered in our previous studies to pubertal rats, that caused the quantitative inhibition of spermatogenesis without changes in FSH levels and the increase in germ and Sertoli cells apoptosis [20, 21]. The second, lower 10-times lower dose of E was chosen on the analogy of previous reports, presenting that administration of E or DES in doses of $0.1-1.0 \mu \mathrm{g}$ in different experimental regimes to immature rats [18] or bank voles [22] had none or even positive effects on testes growth and spermatogenesis. Doses of ZEA were established basing on its binding affinity to ERs [12] and simultaneously on levels of ZEA occurring in environment [23]. The substances were dissolved in dimethyl sulfoxide (DMSO) and olive oil. All the injected substances were purchased from Sigma-Aldrich Co. (St. Louis, MO, USA). Control group (C) was injected with solvents. Each experimental group contained 7-13 newborn animals. Autopsy was performed on the $16^{\text {th }}$ p.d. Animals were anaesthetised with methohexital sodium (Brietal, Eli Lilly, USA) and fentanyl (Fentanyl, Polfa, Poland) and weighted. Both testes were dissected, weighted, fixed in Bouin's fluid and embedded in paraffin.

Morphometry and stereometry of seminiferous tubules. Paraffin embedded testes were cut into $3 \mu \mathrm{m}$ thick sections and stained with haematoxylin and eosin (Bio-Optica, Italy). Morphometric analyses were performed using image analysis software LxAND v3.60HM (Logitex, Lodz, Poland). Diameters of 20 randomly selected seminiferous tubules' cross-sections were measured for each animal. Subsequently, point counting of seminiferous tubules' volume density $(\mathrm{Vv})$ was performed. The microscopic picture at 160x magnification was covered by a square lattice containing 441 intersections. The number of intersections (points) falling on the examined tubular cross-sections was counted by systematic movement across the grid without overlap over the entire tissue section. Volume density $\left(\mathrm{V}_{\mathrm{v}}\right)$ of the seminiferous tubules was obtained by dividing the sum of points on tubular cross-sections by the total number of points over the tissue. The results were expressed as a percentage of the testis volume $\left(\mathrm{V}_{\mathrm{v}} \%\right)$ [24]. Total seminiferous tubules' volume $(\mathrm{V})$ was determined by multiplying their volume density $\left(\mathrm{V}_{\mathrm{v}}\right)$ by fresh testis' volume $\left(\mathrm{V}_{\mathrm{T}}\right): \mathrm{V}=\mathrm{V}_{\mathrm{v}} \cdot \mathrm{V}_{\mathrm{T}}$. The specific gravity of testicular tissue is about $1.04 \mathrm{~g} / \mathrm{cm}^{3}$, thus we used the values obtained for testicular weight as being equivalent to the fresh testis volume. The total length of the seminal tubules (L) was calculated using the transformed standard equation for a tube model $\left(\mathrm{L}=\mathrm{V} / \pi \mathrm{r}^{2}\right)$ [25], where $\mathrm{V}$ was the total seminiferous tubules' volume and $\mathrm{r}$ was the mean radius of the tubule.

Quantitative assessment of seminiferous epithelium cells. In testes of 16-day-old rats spermatogonia $\mathrm{A}(\mathrm{SgA})$, intermediate spermatogonia $(\mathrm{SgIn})$, spermatogonia $\mathrm{B}(\mathrm{SgB})$, spermatocytes in perelptotene (ScPL), leptotene $(\mathrm{ScL})$, zygotene $(\mathrm{ScZ})$ and pachytene (ScPA) stage of the first meiosis and Sertoli cells (S) can be distinguished, basing on their morphological characteristics and location in the seminiferous epithelium as described previously [26]. Particular cell types were counted in 20 randomly chosen round seminiferous tubules' cross-sections for each animal. The diameters of 50 round nuclei of each type of germ and Sertoli cells were measured by means of image analysis software LxAND v3.60HM (Logitex, Lodz, Poland). Because of irregular or oval shape of SgA, SgIn and Sertoli cells nuclei, they were estimated as the average of minimal and maximal dimensions. The counts of different cell types were corrected for section thickness and nucleus diameter [27] and expressed as a cell number per cross-section of seminiferous tubule. The total number of germ and Sertoli cells per testis was calculated from the product of total length of seminiferous tubule and cell numbers expressed per cross-section [28]. For this presentation $\mathrm{SgA}, \mathrm{SgIn}$ and $\mathrm{SgB}$ were joined in $\mathrm{A} / \mathrm{In} / \mathrm{B}$ group, as well as $\mathrm{ScL}, \mathrm{ScZ}$ and ScPA were joined in L/Z/PA group.

Statistical analysis. One-way ANOVA followed by a post hoc test (Newman-Keuls test) was applied to assess statistical significance of the data. Differences were considered significant at $\mathrm{p}<0.05$. Data are presented as mean \pm standard deviation. 
A [mg]

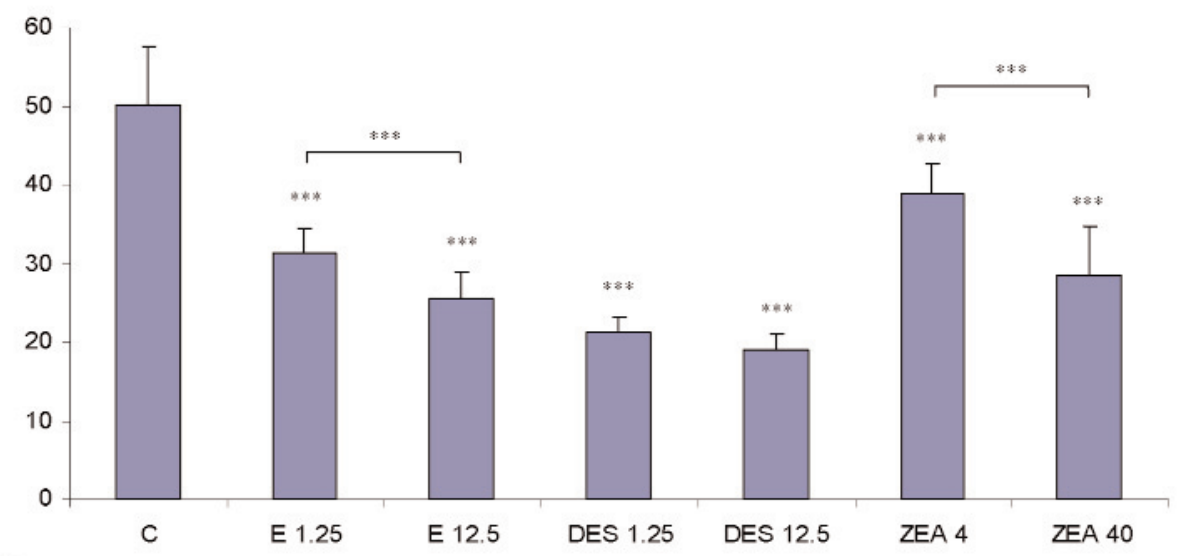

B

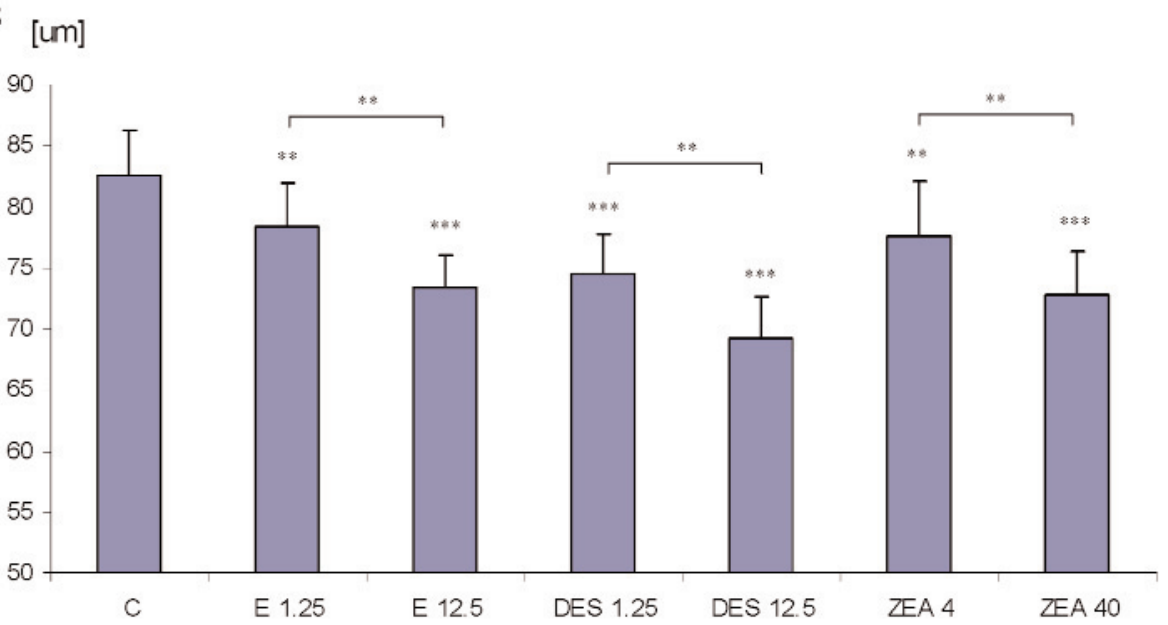

C

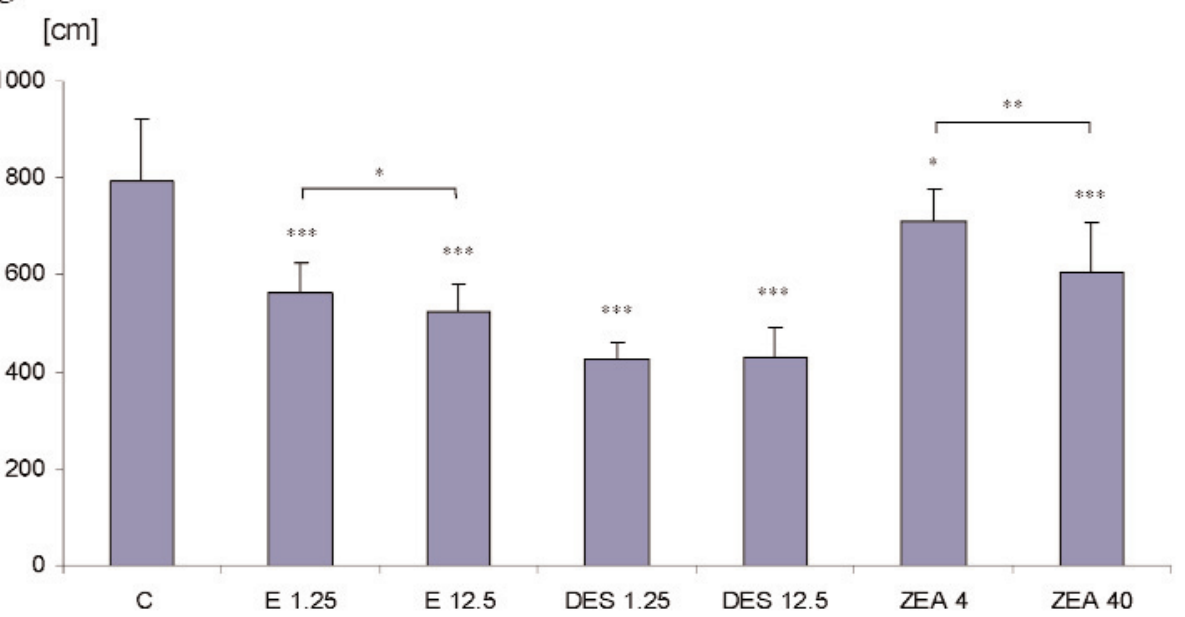

Fig. 1 A-C. Influence of E1.25 $\mu \mathrm{g}$, E12.5 $\mu \mathrm{g}, \mathrm{DES} 1.25 \mu \mathrm{g}, \mathrm{DES} 12.5 \mu \mathrm{g}$ ZEA40 $\mu \mathrm{g}$ and ZEA4 $\mu \mathrm{g}$ per animal per day on testes relative weight (A), seminiferous tubule diameter (B) and seminiferous tubule length (C) in 16-day-old rats. Results are means and standard deviations of 7-13 animals per group. $*-\mathrm{p}<0.05$, ** $\mathrm{p}<0.01, * * *-\mathrm{p}<0.001 ;$ NewmanKauls test, groups vs. control.

\section{Results}

\section{Body and testis weight}

Body weight did not change significantly in all experimental groups (data not shown). Estrogenic and xenoestrogenic treatments caused the significant decrease of testis weight in all groups (Fig. 1A). How- ever, the effect of DES was the strongest in comparison with both doses of E and ZEA and independent of the dose used. Testis weight was diminished to 42 and $38 \%$ of C by DES1.25 and DES12.5, respectively. The effect of $E$ and ZEA treatment was weaker and dose dependent. E1.25 diminished testis weight to $63 \%$ and E12.5 to $51 \%$ of C, while ZEA4 to $77 \%$ and ZEA40 to $57 \%$. 

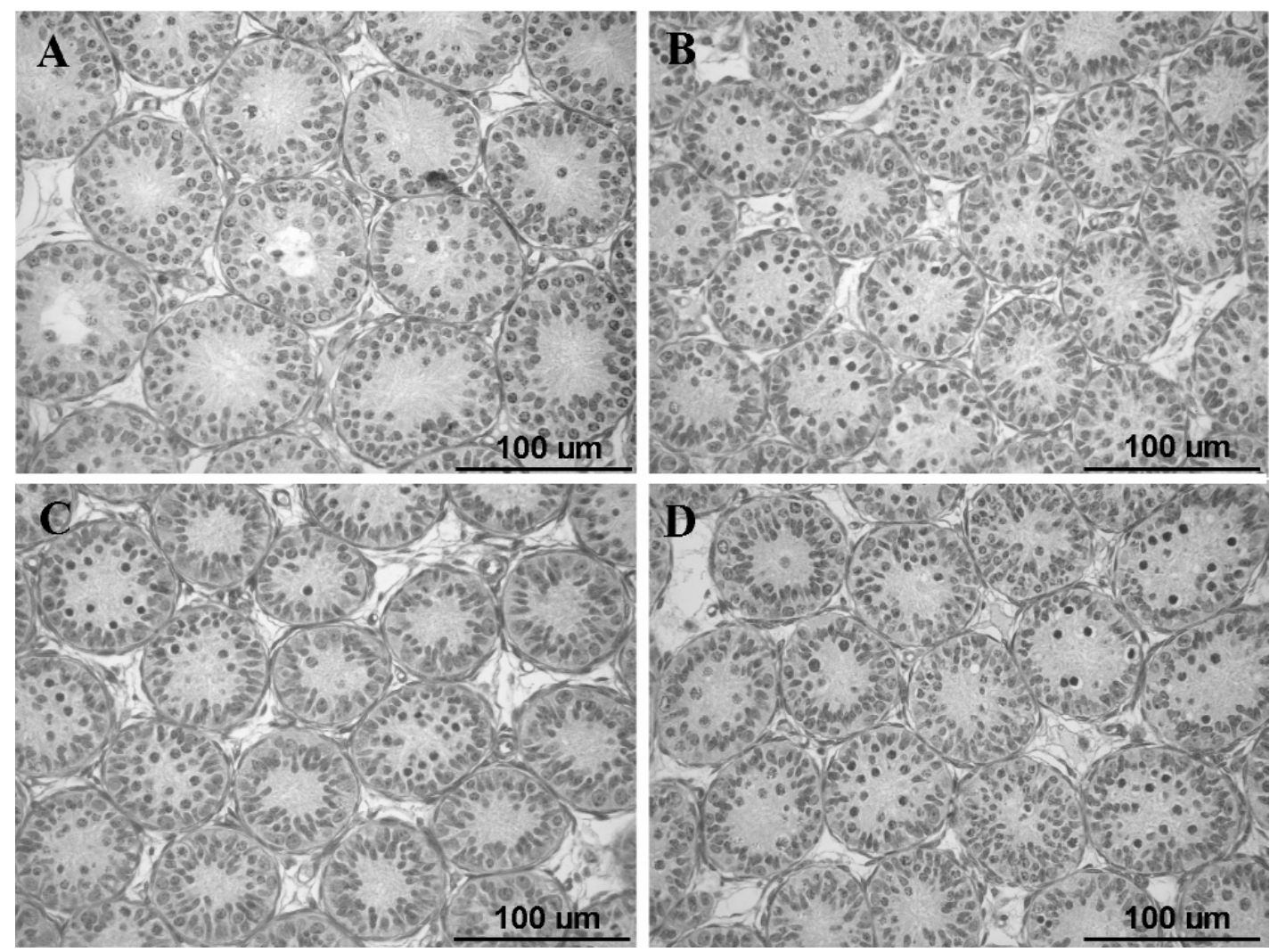

Fig. 2 A-D. Haematoxylin and eosin staining of testis cross-section of 16-day-old rats in control group (A), after treatment with E12.5 $\mu \mathrm{g}$ (B) or DES12.5 $\mu \mathrm{g}$ (C) or ZEA40 $\mu \mathrm{g}$ (D). Seminiferous tubule diameters are significantly diminished by all treatments.

\section{Morphometry and stereometry of seminiferous tubules}

Mean diameter of seminiferous tubules was significantly diminished after all treatments in comparison with C (Fig. 1B). The effects were dose dependent. DES in the higher dose caused the strongest effect, diminishing mean seminiferous tubule diameter to $84 \%$ of C. E12.5, DES1.25 and ZEA40 diminished seminiferous tubule to the same extend (about $89 \%$ of C), as well as E1.25 and ZEA4 revealed similar effects (seminiferous tubule diameter diminished to $95 \%$ of C). Histological pictures of representative seminiferous tubules cross-sections after E12.5, DES12.5 and ZEA40 treatments are presented on the figure 2 A-D.

Mean total length of seminiferous tubules in all groups was significantly decreased after all treatments in comparison with C (Fig. 1C). The effect of DES was the strongest and independent of the used dose. E1.25, E12.5 and ZEA40 had similar influence on seminiferous tubule length, while ZEA4 showed the weakest effect.

\section{Quantitative assessment of seminiferous epithelium cells}

DES, independently of the doses used, had the most detrimental effect on each type of germ cells number.
The negative influence of $\mathrm{E}$ on germ cell numbers was less pronounced causing, after administration of both doses, the decrease of $\mathrm{A} / \mathrm{In} / \mathrm{B}$ number (E1.25 to $62 \%$, E12.5 to 59\% of C). Significant decrease in ScPL number (to $39 \%$ of C) was observed only after treatment with E12.5. The effect of ZEA was the weakest, exerted significantly only after higher dose on spermatogonia number $(\mathrm{A} / \mathrm{In} / \mathrm{B}$ decreased to $66 \%$ of $\mathrm{C})$. The effect of the administered compounds on germ cell number is shown on the Fig. 3A.

The number of somatic Sertoli cells per testis was significantly diminished by all of the substances except ZEA4 (Fig. 3B). Again, the strongest effect was observed after treatment with DES and this effect was independent on the used dose (decreased to $46-48 \%$ of C). E in both doses and ZEA40 caused similar decrease in Sertoli cell number, but the effect was weaker than the effect of DES. ZEA4 did not influence Sertoli cell number.

\section{Discussion}

We performed our study in the specific period of rat's life between the $5^{\text {th }}$ and $15^{\text {th }}$ day after birth. On the $5^{\text {th }}$ day of life fetal germ cells, gonocytes, are already differentiated into the first spermatogonia. We analyzed the next 10 days, the period covering the first appear- 
A

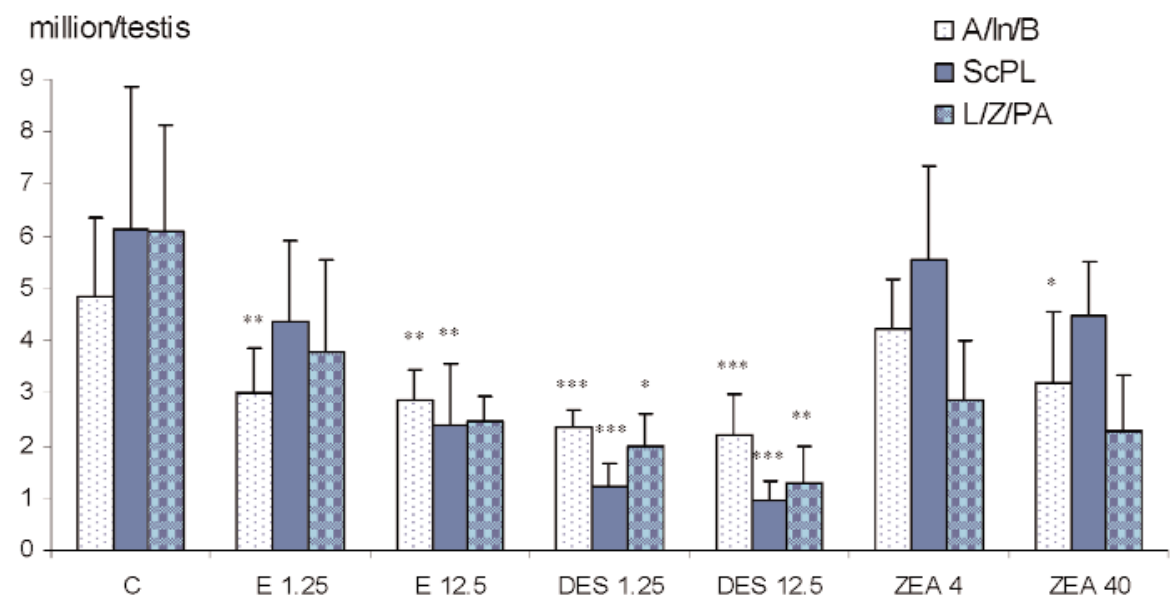

B

million/testis

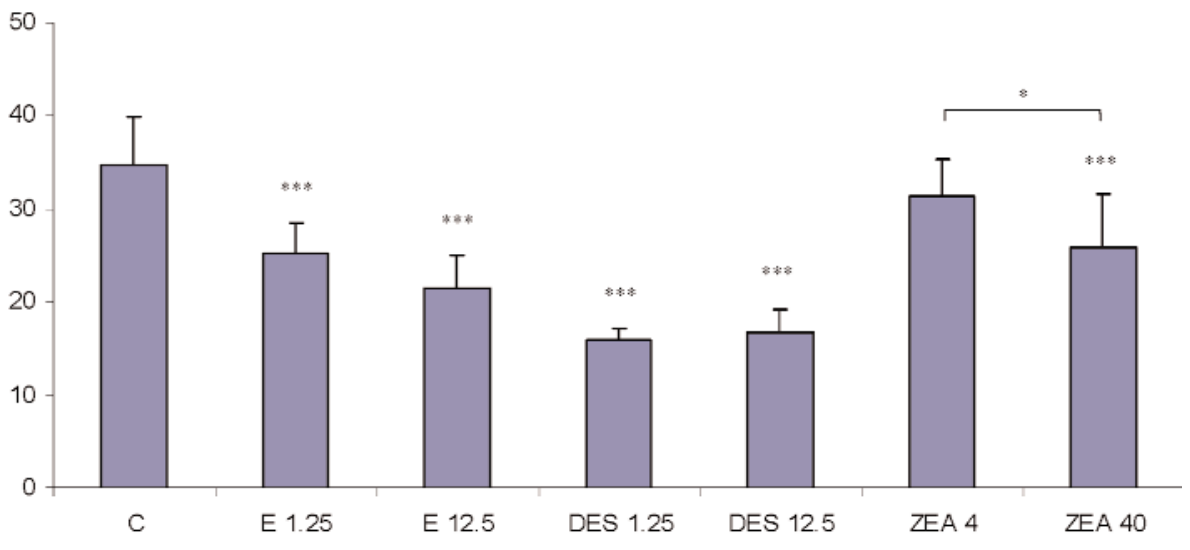

Fig. 3 A-B. Influence of E1.25 $\mu \mathrm{g}$, E12.5 $\mu \mathrm{g}$, DES1.25 $\mu \mathrm{g}$, DES12.5 $\mu \mathrm{g}$ ZEA40 $\mu \mathrm{g}$ and ZEA4 $\mu \mathrm{g}$ per animal per day on germ cell number per testis (A) and Sertoli cells number per testis (B) in 16-day-old rats. Results are means and standard deviations of 7-13 animals per group. * $\mathrm{p}<0.05, * *-\mathrm{p}<0.01, * * *-\mathrm{p}<0.001$; Newman-Keuls test, groups vs. control. A/In/B - spermatogonia A, intermediate and $\mathrm{B}$; ScPL - spermatocytes preleptotene stage; L/Z/PA spermatocytes in leptotene, zygotene and pachytene stage. ance of $\mathrm{SgA}$, their multiplication and differentiation into $\mathrm{SgIn}$ and $\mathrm{SgB}$, progression into meiotic germ cells - ScPL and the transition between ScPL and ScPA, representing prophase of the first meiotic division [26, 29,30]. To our knowledge the studies on E and DES influence on the rat's testis development are numerous $[3,9,16]$ but the influence of ZEA on testis and spermatogenesis of the 16-day-old rats is reported for the first time. However, there are results of studies on zeranol, ZEA derivative, suggesting that it can impair spermatogenesis and testis development after birth by disruption of hormonal/FSH balance [31].

There are a lot of opposing results of studies on the influence of estrogen like substances on the developing testis up to puberty $[9,16]$. In general, perinatal exposure to high doses of substances with the high estrogenic activity, such as E and DES, led to severe retardation of first spermatogenesis and testicular development $[2,18,32,33]$. Our results are in agreement with these studies and confirmed that all of the analyzed substances, including natural estrogen, had the detrimental effect on the germ and Sertoli cells number, as well as on the testis weight, diameter and length of seminiferous tubules. One of the possible explanation of this negative impact is that high levels of estrogen may cause a reduction in both GnRH secretion and pituitary responsiveness to GnRH [34], as well as the decrease in FSH and LH blood concentration, and as a consequence in testosterone production [35]. However, the direct effect of estrogen on testicular cells cannot be ruled out. Estrogen directly can retard pubertal Leydig cells development [36] and inhibit testosterone production [21,37]. Moreover, estrogen may have the direct negative influence on Sertoli cell number and maturation, independently of changes in FSH and androgen levels [38,39].

In our study DES had the strongest harmful effect on each analyzed parameter in the developing testis in low and 10-times higher doses. Testicular weight, seminal tubule length and all germ cell types and Sertoli cell number were significantly decreased. Atanassova et al. revealed also inhibitory effect of DES on the first spermatogenesis in rats receiving similar dose $(10 \mu \mathrm{g} /$ day $)$ between the $2^{\text {th }}$ and $12^{\text {th }}$ p.d., however, after lower doses $(0.01$ or $0.1 \mu \mathrm{g} /$ day) some stimulatory effects were observed [18]. It is of interest that FSH serum levels were elevated in early puberty (after treatment has ceased) and such a change persisted to 
adulthood. The mutual action of FSH and estrogen was also reported in our previous study when concomitant administration of estradiol benzoate and FSH to immature rats resulted in the enhancement of FSH stimulatory effect on the initiation of spermatogenesis by estrogen [21]. Lim et al. [40] reported recently that Estimulated spermatogenic development in hpg mice occurred with markedly suppressed intratesticular E levels. Authors suggested that this inducing effect of $\mathrm{E}$ on spermatogenesis is caused by extratesticular $\mathrm{E}$ actions, predominantly increase in FSH level, what was also suggested before by Ebling et al. [41]. It is possible that the failure in achieving a positive effect of lower dose of $\mathrm{E}$ on germ cells in our present study is caused by the fact that the dose used was not able to exert stimulating effect on FSH secretion. The reduction in number of spermatogonia, as well as in Sertoli cells, suggests rather opposite effect. The comparable detrimental effect of both doses of DES on testes development, germ and Sertoli cell numbers seen in our study, may suggest that probably after crossing the certain threshold of estrogen level in the blood its effect is less dependent on administered doses.

DES is known to have more estrogenic activity than $\mathrm{E}$ in vitro and in vivo [42,43]. In accordance with this, the negative effects of $E$ in our study, administered in the same doses as DES, were less pronounced and showed a clear dose-dependent pattern for most of the parameters studied. Both doses of $\mathrm{E}$ inhibited the number of Sertoli cells and spermatogonia, however inhibition of germ cell types of further steps of spermatogenesis were observed only after the higher dose of E. Spermatogonia number, as only germ cell type, was decreased after administration of all studied substances except the lower dose of ZEA. It may suggest that spermatogonia seem to be the most sensitive to the negative impact of used here substances. These results are in conflict with our earlier studies in which estradiol benzoate was administered to rats during the neonatal period of life between days $5^{\text {th }}$ and $11^{\text {th }}$, showing that the numbers of undifferentiated and differentiating type A spermatogonia were increased at day $15^{\text {th }}$ [44]. One of the possible explanations for these discrepancies can be the use of an estradiol compound (estradiol benzoate) in our previous study instead of pure $\mathrm{E}$, which binding affinity to the human and murine ER $\alpha$ seems to be 6-10-fold reduced in comparison with $\mathrm{E}$ [45]. As the ER $\alpha$ is the main ER expressed in the rat pituitary gland [46] the differences in the effects exerted by both substances could be attributed to their different action on gonadotropins secretion, suggesting inhibition of FSH by E. The selective suppression of FSH action in immature rats by passive immunisation caused a significant reduction in Sertoli cells and spermatogonia numbers, but spermatocytes were more resistant to this conditions [47]. Therefore the reduction in spermatogonia number obtained in this study by administration of DES and E were attributed rather to probable inhibition of FSH action, although the direct action on germ cells cannot be totally ruled out. It is probable also that Sertoli cells are the main target for the harmful influence of estrogen. It was found previously that DES exposure during postnatal, prepubertal period of life caused delay in advance of spermatogenesis and consequently reduced daily sperm production and testis weight in adulthood, because of delayed Sertoli cell maturation and impaired function, and decrease in their number [38,39].

ZEA is known to have lower estrogenicity in comparison to $E$ and DES [12]. According to this in our study ZEA had the weakest effect on almost all analyzed parameters. It had significant dose dependent effect on testicular growth but the effect on spermatogenesis was not so evident. ZEA influence on the numbers of different types of germ cells (besides spermatogonia after ZEA40) was not statistically significant and Sertoli cell number was diminished significantly only by the higher dose of ZEA. It was shown previously that single peritoneal injection of ZEA $(5 \mathrm{mg} / \mathrm{kg})$ to adult male rats caused germ cell apoptosis. The main target cells in ZEA-induced apoptosis were spermatogonia and early spermatocytes [14]. Thus, the decrease in spermatogonia number in our study can be probably attributed to the increased rate of their apoptosis, but it needs further elucidation. It was also shown in vitro that ZEA significantly suppressed hCG-induced testosterone production in Leydig cells from adult mice [48]. It has been shown that testosterone withdrawal increased the apoptotic rate almost in all stages of spermatogenesis in adult rats and had the most detrimental effect on preleptotene spermatocytes survival [49]. In our study the significant decrease was evident only for the number of spermatogonia after administration of the higher dose of ZEA, thus the decrease in testosterone level cannot be probably the only explanation. However, in adult male rats treated orally with $20 \mathrm{mg}$ of ZEA for 5 weeks there were no changes in testes weight, as well as in spermatogenesis and serum levels of gonadotropins [50]. The question if FSH could attribute to the negative effect of ZEA on spermatogonia and Sertoli cell numbers needs further exploration, and such studies are in progress.

\section{Conclusions}

Exposure of prepubertal male rats to DES has stronger detrimental effect on the developing testis in comparison to the effect of natural estrogen and weak xenoestrogen ZEA. E and xenoestrogens diminished seminiferous tubule diameter, length and testis weight. However, there were differences in severity of the effects and dose-dependency. E and DES in both doses impaired spermatogenesis, especially decreased spermatogonia number. ZEA had weaker effect than the 
potent estrogens. Only the higher dose of ZEA mimicked to some extent the inhibitory effect of $E$ and DES. Taking into account the usual oral way of ZEA administration in rodents and human we may suspect that its concentration in the organism is lower in comparison to subcutaneous administration and the real effect is probably less intensive. Nevertheless, according to other studies, ZEA may have the negative influence on the fertility in adulthood.

Acknowledgements: Financial support by grant of Medical University in Lodz no 502-11-565 and 503-1089-2/3.

\section{References}

[1] Carreau S, Bourguiba S, Lambard S, Galeraud-Denis I, Genissel C, Levallet J. Reproductive system: aromatase and estrogens. Mol Cell Endocrinol. 2002;193:137-143.

[2] Sharpe RM. The roles of oestrogen in the male. Trends Endocrinol Metab. 1998;9:371-377.

[3] O'Donnell L, Robertson K, Jones M, Simpson E. Estrogens and spermatogenesis. Endocr Rev. 2001;289-318.

[4] Hejmej A, Gorazd M, Kosiniak-Kamysz K, Wiszniewska B, Sadowska J, Bilinska B. Expression of aromatase and oestrogen receptors in reproductive tissues of the stallion and a single cryptorchid visualised by means of immunohistochemistry. Domest Anim Endocrinol. 2005;29:534-547.

[5] Saunders PT, Fisher JS, Sharpe RM, Millar MR. Expression of oestrogen receptor beta (ER beta) occurs in multiple cell types, including some germ cells, in the rat testis. J Endocrinol. 1998;156:R13-17.

[6] van Pelt AM, de Rooij DG, van der Burg B, van der Saag PT, Gustafsson JA, Kuiper GG. Ontogeny of estrogen receptorbeta expression in rat testis. Endocrinology. 1999;140:478483.

[7] Allsopp M, Santillo D and Johnston P. Poisoning the future; Impacts of endocrine disrupting chemicals on wildlife and human health. Greenpeace; 1997.

[8] Slowikowska-Hilczer J. Xenobiotics with estrogen or antiandrogen action - disruptors of the male reproductive system. Cent Eur J Medicine. 2006;1:205-227.

[9] McLachlan JA. Environmental signaling: what embryos and evolution teach us about endocrine disrupting chemicals. Endocr Rev. 2001;22:319-341.

[10] Newbold R, Bullock B, McLachlan J. Testicular tumors in mice exposed in utero to diethylstilbestrol. J Urol. 1987; 138:1446-1450.

[11] Atanassova N, McKinnell C, Walker M, Turner KJ, Fisher JS, Morley M, Millar MR, Groome NP, Sharpe RM. Permanent effects of neonatal estrogen exposure in rats on reproductive hormone levels, Sertoli cell number, and the efficiency of spermatogenesis in adulthood. Endocrinology. 1999;140:5364-5373.

[12] Kuiper GG, Lemmen JG, Carlsson B, Corton JC, Safe SH, van der Saag PT, van der Burg B, Gustafsson JA. Interaction of estrogenic chemicals and phytoestrogens with estrogen receptor beta. Endocrinology. 1998;139:4252-4263.

[13] Zinedine A, Soriano JM, Molto JC, Manes J. Review on the toxicity, occurrence, metabolism, detoxification, regulations and intake of zearalenone: an oestrogenic mycotoxin. Food Chem Toxicol. 2007;45:1-18.

[14] Kim IH, Son HY, Cho SW, Ha CS, Kang BH. Zearalenone induces male germ cell apoptosis in rats. Toxicol Lett. 2003;138:185-192.

[15] Benzoni E, Minervini F, Giannoccaro A, Fornelli F, Vigo D,
Visconti A. Influence of in vitro exposure to mycotoxin zearalenone and its derivatives on swine sperm quality. Reprod Toxicol. 2008;25:461-467.

[16] Sharpe RM. Pathways of endocrine disruption during male sexual differentiation and masculinization. Best Pract Res Clin Endocrinol Metab. 2006;20:91-110.

[17] Kim HS, Kim TS, Shin JH, Moon HJ, Kang IH, Kim IY, Oh JY, Han SY. Neonatal exposure to di(n-butyl) phthalate (DBP) alters male reproductive-tract development. J Toxicol Environ Health A. 2004;67:2045-2060.

[18] Atanassova N, McKinnell C, Turner KJ, Walker M, Fisher JS, Morley M, Millar MR, Groome NP, Sharpe RM. Comparative effects of neonatal exposure of male rats to potent and weak (environmental) estrogens on spermatogenesis at puberty and the relationship to adult testis size and fertility: evidence for stimulatory effects of low estrogen levels. Endocrinology. 2000;141:3898-3907.

[19] Mikkila TF, Toppari J, Paranko J. Effects of neonatal exposure to 4-tert-octylphenol, diethylstilbestrol, and flutamide on steroidogenesis in infantile rat testis. Toxicol Sci. 2006;91:456-466.

[20] Walczak-Jedrzejowska R, Slowikowska-Hilczer J, Marchlewska K, Kula K. Maturation, proliferation and apoptosis of seminal tubule cells at puberty after administration of estradiol, follicle stimulating hormone or both. Asian J Androl. 2008; 10:585-592

[21] Kula K, Walczak-Jedrzejowska R, Slowikowska-Hilczer J, Oszukowska E. Estradiol enhances the stimulatory effect of FSH on testicular maturation and contributes to precocious initiation of spermatogenesis. Mol Cell Endocrinol. 2001;178:89-97.

[22] Gancarczyk M, Paziewska-Hejmej A, Carreau S, Tabarowski Z, Bilinska B. Dose- and photoperiod-dependent effects of 17beta-estradiol and the anti-estrogen ICI 182,780 on testicular structure, acceleration of spermatogenesis, and aromatase immunoexpression in immature bank voles. Acta Histochem. 2004; $106: 269-278$

[23] CCFAC: Codex Committee of Food Additives and Contaminants. Joint FAO/WHO Expert Committee on Food Additives: Position paper on zearalenone. Publication CCFAC 00/19. Codex Alimentarius Commission. InRome, Italy, 2000.

[24] Mori H, Christensen AK. Morphometric analysis of Leydig cells in the normal rat testis. J Cell Biol. 1980;84:340-354.

[25] Wing TY, Christensen AK. Morphometric studies on rat seminiferous tubules. Am J Anat. 1982;165:13-25.

[26] Clermont Y, Perey B. Quantitative study of the cell population of the seminiferous tubules in immature rats. Am J Anat. 1957; 100:241-267.

[27] Abercrombie M. Estimation of nuclear population from microtome sections. Anat Rec. 1946;238-247.

[28] Marshall GR, Plant TM. Puberty occurring either spontaneously or induced precociously in rhesus monkey (Macaca mulatta) is associated with a marked proliferation of Sertoli cells. Biol Reprod. 1996;54:1192-1199.

[29] Kula K. The completion of spermatogenic cells in the course of spermatogenesis in immature rats. Folia Morphol. 1977;36:167-173

[30] Russell LD, Alger LE, Nequin LG. Hormonal control of pubertal spermatogenesis. Endocrinology. 1987;120:16151632.

[31] Marois G, Marois M. Comparison of the action of an impeded estrogen, frideron, and of estradiol on the seminal vesicles and on the weight of the testicles and accessory sex glands in the rat. II. J Gynecol Obstet Biol Reprod (Paris). 1979;8:101105.

[32] Behrens GH, Petersen PM, Grotmol T, Sorensen DR, Torjesen P, Tretli S, Haugen TB. Reproductive function in male 
rats after brief in utero exposure to diethylstilboestrol. Int $J$ Androl. 2000;23:366-371.

[33] Fisher JS, Turner KJ, Brown D, Sharpe RM. Effect of neonatal exposure to estrogenic compounds on development of the excurrent ducts of the rat testis through puberty to adulthood. Environ Health Perspect. 1999;107:397-405.

[34] Pinilla L, Garnelo P, Gaytan F, Aguilar E. Hypothalamic-pituitary function in neonatally oestrogen-treated male rats. J Endocrinol. 1992;134:279-286.

[35] Bellido C, Pinilla L, Aguilar R, Gaytan F, Aguilar E. Possible role of changes in post-natal gonadotrophin concentrations on permanent impairment of the reproductive system in neonatally oestrogenized male rats. J Reprod Fertil. 1990;90:369374.

[36] Abney TO. The potential roles of estrogens in regulating Leydig cell development and function: a review. Steroids. 1999;64:610-617.

[37] Knobil E, Neill J. The Phisiology of Reproduction. New York: Raven Press; 1994.

[38] Sharpe RM, Atanassova N, McKinnell C, Parte P, Turner KJ, Fisher JS, Kerr JB, Groome NP, Macpherson S, Millar MR, Saunders PT. Abnormalities in functional development of the Sertoli cells in rats treated neonatally with diethylstilbestrol: a possible role for estrogens in Sertoli cell development. Biol Reprod. 1998;59:1084-1094.

[39] Atanassova NN, Walker M, McKinnell C, Fisher JS, Sharpe RM. Evidence that androgens and oestrogens, as well as follicle-stimulating hormone, can alter Sertoli cell number in the neonatal rat. $J$ Endocrinol. 2005;184:107-117.

[40] Lim P, Allan CM, Notini AJ, Axell AM, Spaliviero J, Jimenez M, Davey R, McManus J, MacLean HE, Zajac JD, Handelsman DJ. Oestradiol-induced spermatogenesis requires a functional androgen receptor. Reprod Fertil Dev. 2008;20:861870 .

[41] Ebling FJ, Brooks AN, Cronin AS, Ford H, Kerr JB. Estrogenic induction of spermatogenesis in the hypogonadal mouse. Endocrinology. 2000;141:2861-2869.
[42] Kuiper GG, Carlsson B, Grandien K, Enmark E, Haggblad J, Nilsson S, Gustafsson JA. Comparison of the ligand binding specificity and transcript tissue distribution of estrogen receptors alpha and beta. Endocrinology. 1997;138:863-870.

[43] Jefferson WN, Padilla-Banks E, Clark G, Newbold RR. Assessing estrogenic activity of phytochemicals using transcriptional activation and immature mouse uterotrophic responses. J Chromatogr B Analyt Technol Biomed Life Sci. 2002;777:179-189.

[44] Kula K. Induction of precocious maturation of spermatogenesis in infant rats by human menopausal gonadotropin and inhibition by simultaneous administration of gonadotropins and testosterone. Endocrinology. 1988;122:34-39.

[45] Matthews J, Celius T, Halgren R, Zacharewski T. Differential estrogen receptor binding of estrogenic substances: a species comparison. J Steroid Biochem Mol Biol. 2000;74:223-234.

[46] Pelletier G. Localization of androgen and estrogen receptors in rat and primate tissues. Histol Histopathol. 2000;15:12611270.

[47] Meachem SJ, Robertson DM, Wreford NG, McLachlan RI, Stanton PG. Oestrogen does not affect the restoration of spermatogenesis in the gonadotrophin-releasing hormone-immunised adult rat. $J$ Endocrinol. 2005;185:529-538.

[48] Yang J, Zhang Y, Wang Y, Cui S. Toxic effects of zearalenone and alpha-zearalenol on the regulation of steroidogenesis and testosterone production in mouse Leydig cells. Toxicol In Vitro. 2007;21:558-565.

[49] Henriksen K, Hakovirta H, Parvinen M. In-situ quantification of stage-specific apoptosis in the rat seminiferous epithelium: effects of short-term experimental cryptorchidism. Int $J$ Androl. 1995;18:256-262.

[50] Milano G, Becu-Villalobos D, Tapia M. Effects of long-term zearalenone administration on spermatogenesis and serum luteinizing hormone, follicle-stimulating hormone, and prolactin values in male rats. Am J Vet Res. 1995;Jul 56:954-958. 